\title{
Flood Susceptibility Based Geomorphological Approach in Sitiarjo Village, Sumbermanjing Wetan, Malang Regency
}

\author{
Maulana Yudinugroho ${ }^{1}$, Krishna Aji Wijaya ${ }^{1}$, Isna Pujiastuti ${ }^{1}$, Ratih \\ Winastuti ${ }^{1}$,Muhammad Thariq ${ }^{1}$, Muhammad Fariq ${ }^{1}$, Djati Mardiatno ${ }^{1}$ \\ ${ }^{1}$ Department of Environmental Geography, Faculty of Geography, Universitas Gadjah \\ Mada, Indonesia \\ Correspondence: maulana.yudinugroho@gmail.com
}

\begin{abstract}
Sitiarjo is an agriculture area located at a downstream part of Penguluran Watershed System. Due to geometric factor of the watershed system and heavy rainfall on wet season, this village has been flooded annually in the last 10 years. There were no casulaties reported but the impact caused the economic losses. The aim of this research was to identify the geomorphological characteristics related to spatial distribution of flood susceptibility in Sitiarjo Village, Sumbermanjing Wetan, Malang Regency. The data were collected from secondary data e.g. maps, report from agency and other source and primary data from observation and investigation in the field. The geomorphological map was resulted from secondary data from DEM and geological map. Distance to river, river flow density, and slope parameters were used to compose the flood susceptibility map. Each parameter validated through fieldwork. Geomorphological map was used to analyze the flood susceptibility distribution in Sitiarjo. Results showed geomorphological characteristics are well correlated with the flood susceptibility

distribution.
\end{abstract}

\section{Introduction}

The consequences of Indonesia's geographic feature as the region located in monsoonal zone is that there are only two seasons occurred, wet and dry season. Several places in Indonesia are vulnerable to flood event in wet season due to high rainfall. Flood occurred in many places of Indonesia. Sitiarjo Village is one of many areas that are often flooded. The most memorable flood for Sitiarjo's community has occurred in 1993, 2003, 2007, 2010, and 2013. Flood events in 2013 was the most severe flood that caused 2.787 people affected by flood. Moreover, 166 hectares rice fields are severely damaged and threatened by crop failures and 45 hectares of banana plantations were damaged [1]. Though, most of the Sitiarjo's vilagers livelihood as a farmer. Flood is serious interference for them.

Flood is strongly related to watershed system feature and its management. Sitiarjo is located in the downstream zone of Penguluran Watershed. Its system shape was classified as rounded waterhed. This watershed has unique hydrologic pattern due to its morphometry 
system. The highest peak of discharge reached more quickly than the normal condition. The round shape watershed has the drainage pattern at upperstream were accumulated into one channel at the downstream thus resulting the overflow river flood more often to occur even no rain. This conclution was aslo mentioned by [2] and [3] which the study was proof that oval to round have a medium to high tendecy of flood occurences.

Penguluran River is an old aged river which showed meandering pattern at the downstream. While the upperstream has a dendritic pattern watercourse with a steep gradient slope. This caused the massive hydrologic response when it was raining. A steep slope tend to produce runoff faster instead of infiltrate the rain water. As a result the water immediately flow and accumulated to downstream of Penguluran River. Thus, Sitiarjo which was a place where confluence of watercourse and main channel potentially vulnerable to stricken flood.

The aim of this study is to identify the geomorphological condition and spatial distribution of flood susceptibility in Sitiarjo Village, Sumbermanjing Wetan, Malang Regency.

\section{Methods}

This research conducted in Sitiarjo Village, Sumbermanjing Wetan Subdistrict, Malang Regency located at the southern part of East Java (Fig. 2). The Village covers an area of $28,962574 \mathrm{~km}^{2}$ with hilly karst in the border of the village and floodplain at the center of the village. The study area lies between $112^{0} 38^{\prime} 50^{\prime \prime}-112040$ ' $30^{\prime \prime} \mathrm{E}$ and $8^{0} 26^{\prime} 50^{\prime \prime}-8^{0} 22^{\prime} 40^{\prime \prime} \mathrm{S}$, Sitiarjo Vilage is located in the downstream of Penguluran Watershed. The climate of the region is Am type, the monsun tropical climate according to the Koppen Classification. Two seasons are wet and dry season that have strong influence to flood occurance. The total population is 7.553 inhabitants. The higest precipitation of this area is aproximatelly varies between $200-410 \mathrm{~mm}$ /day by intense rainfall event during the wes seasons. This study area is characterized by very often the flash flood event occured in the settlement. The specific geographical settings of this village is combination of complex strucltural, karst, and fluvial geomorphology with extensive antropogenic activities.

This research was conducted to analyze the flood susceptibility based on geomorphological approach. Landform characterizations were held to determine flood vulnerability zone based on slope gradient, soil type, and the characteristic of main river in the watershed system. Weight of evidence method was chosen to compose parameter index to make flood vulnerability map. The map result was validated through topographic survey and field work. This work included landform unit characterization which held through a topographic transect. Landform unit was chose as analytical unit considering each landform units have a typical and complex process that works within its system. Result of this research may be expected to give a review for development planning in order to reduce the risk from flood hazard in Sitiarjo. 
Data used secondary data from Maps and satellite imagery and primary data from the field observation. The secondary data used from extracting countur data from topography map of Indonesia (RBI Maps) to generate a Digital Elevation Model (DEM) data, from ESRI Imagery of Sumbermanjing Wetan, Geological Maps of Turen. The secondary data processes into tentative map of geomorphology and tentative flood suceptibility map. Field observatory conducted to validating and correcting the tentative map. The research method represented in Fig. 1.

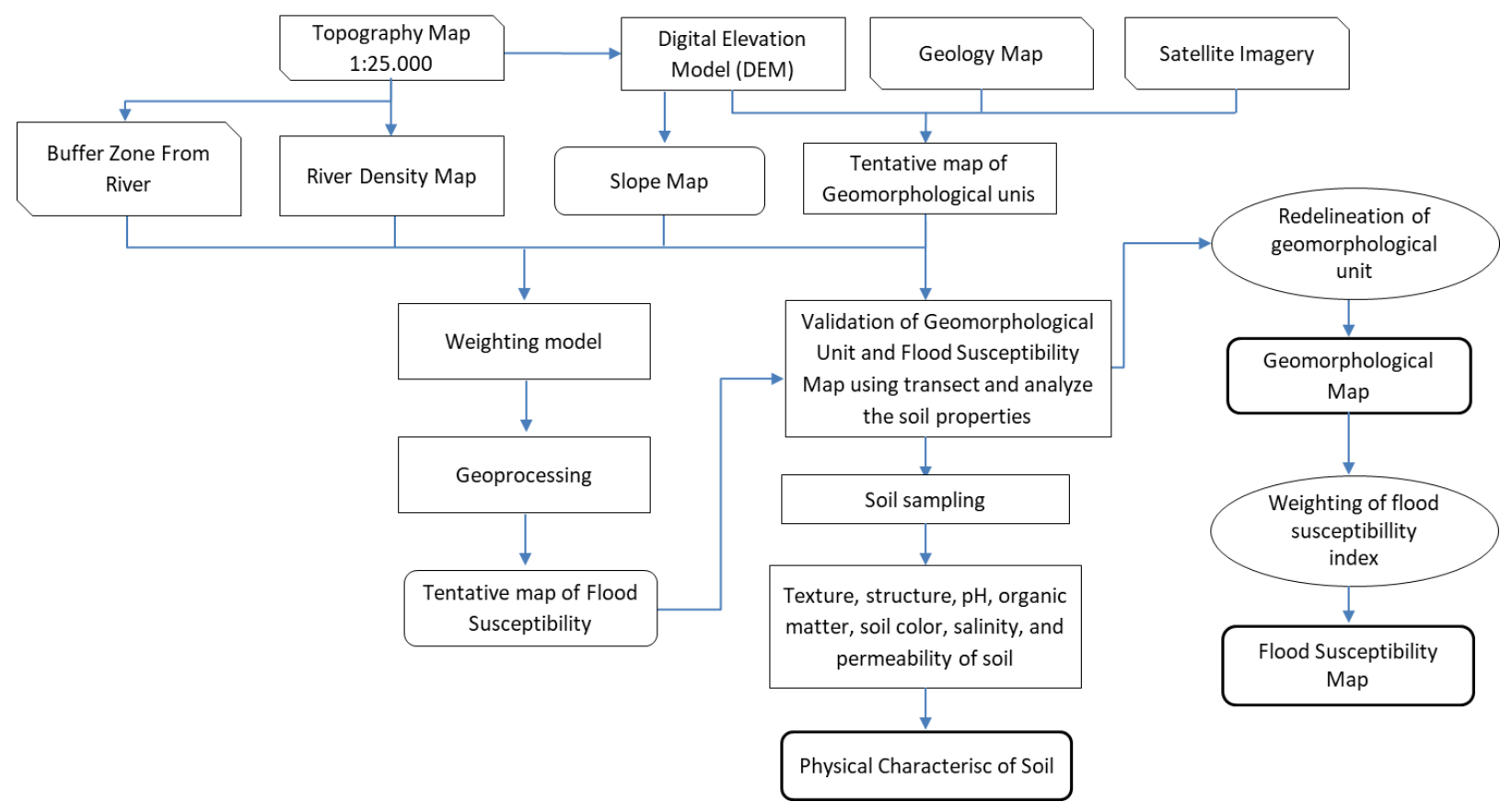

Fig. 1 Flowchart of flood susceptibility assessment employed in this study

\subsection{Geomorphology Mapping}

The geomorpology maps was produced by the combination of slope, DEM, lithology, and geology map. The geomorpology maps was produced in with scale 1:25.000 with landform classification included type, facet, and morphology unit. The morphology map use analytical approach by considering morphometry, morphography/ morphogenesis, morphocronology, and litology on the site. Tentative map of geomorphology as the based of field survey. Field observation conducted through topographic transect section to validate the geomorphology map. Soil properties identification on the field is done on every form of landform unit passed on the transect. Collected geomorphological data and soil properties were taken using purposive sampling method by transect at several locations. 


\subsection{Flood Suceptibility Mapping}

Weight of evidence method was used to composed the parameter using geographic information system (GIS) to make a flood vulnerability map. This method was using several physical parameters and were also ranked and weighted for each parameters. According to [4] that flood vulnerability mainly affected by four parameters, slope, drainage, and distance to main river. These parameters were deducted into several measurable variables. The slope gradient, distance to main river, drainage density were selected as variable to be measured and composed the flood vulnerability map.

These four parameters were weighted according to their relative importance to the flood potential of the river. Each of these parameters was divided into different ranges land classes, and were also ranked (or called as ratings), depending on their relative importance to flood potential. landform unit characteristics response to flood were analyzed through field work by using topographic cross section to obtain surface characteristic and response to flood. This method was also has a purpose to validating the flood vulnerability map and increasing the detail to help determine spatial distribution of flood vulnerability map.

Landform parameter was composed from 4 main landscape in southern part of Malang Regency, especially in Sitiarjo and surroundings. Those landscapes were originated from structural, fluvial, solutional, and marine processes. The landscapes later were detailed into landform unit including the morphology, morphogenesis, and morphoarangement information within it. Landforms covers in study area were ranked and weighted as the flood vulnerability parameter, shown at table 1 .

Table 1. Ratings for landform unit parameter

\begin{tabular}{lc}
\hline \multicolumn{1}{c}{ Landforms } & Rating \\
\hline $\begin{array}{l}\text { Old beach, beach, karst hill, } \\
\text { escarpment, lagoon, tombolo, } \\
\text { structural upperslope and } \\
\text { downslope }\end{array}$ & 1 \\
$\begin{array}{l}\text { Karst plain, colluvial plain, doline, } \\
\text { and estuary }\end{array}$ & 2 \\
$\begin{array}{l}\text { Oxbow lake, river valley } \\
\text { Alluvial plain, flood plain, } \\
\text { backswamp }\end{array}$ & 3 \\
\hline
\end{tabular}

Contour data were extracted Surface Maps of Indonesia, RBI from scale 1:25000 Surface Maps of Indonesia RBI was generated as DEM data. Peta RBI skala 1:25000 has detailed resolution than any source of open data, its contour has interval at 12.5 meter. The DEM later is used to generate slope map and classified according [5] slope classification classified into five classes. The slope classification rating and weight is shown at table 2. 
Table 2. Ratings for slope parameter

\begin{tabular}{cllc}
\hline $\begin{array}{c}\text { Slope } \\
(\%)\end{array}$ & $\begin{array}{c}\text { Slope } \\
\text { Class }\end{array}$ & Unit Morphology & Rating \\
\hline $0-8$ & Plain & Plain & 1 \\
$>8-$ & Undulating & $\begin{array}{l}\text { Hill with smooth } \\
\text { relief }\end{array}$ & 2 \\
15 & Hilly & $\begin{array}{l}\text { Hill with } \\
\text { moderetely relief }\end{array}$ & 3 \\
25 & Hodineous \\
$>25-$ & $\begin{array}{l}\text { Moderately } \\
\text { steep }\end{array}$ & $\begin{array}{l}\text { Mountain moderetely } \\
\text { with }\end{array}$ & 4 \\
& Molief \\
$>45$ & Steep & $\begin{array}{l}\text { Mountaineous } \\
\text { relief }\end{array}$ & 5 \\
\hline
\end{tabular}

Distance to main river parameter was used to determine area near the river. Distance to main river were classified into 4 classes according to survey result about history of the flood occurrence in Sitiarjo. The distance to main river classification rating and weight is shown at table 3 .

Table 3. Ratings for distance from river parameter

\begin{tabular}{ll}
\hline Distance $(\mathbf{m})$ & Rating \\
\hline $0-50$ & 4 \\
$>50-100$ & 3 \\
$>100-150$ & 2 \\
$>150-200$ & 1 \\
\hline
\end{tabular}

Drainage density is a parameter used to determine the stratification of drainage density of a watercourse and indication of meandering river. The assumption applied in this method is that when raining occurs, area with a dense drainage resulting a high flow debit and potentially has a high vulnerable of flood. Drainage density of a watercourse classification rating and weight is shown at table 4 .

Table 4. River Stream Density Rank

\begin{tabular}{ll}
\hline Density & Rank \\
\hline Dense & 3 \\
Moderate & 2 \\
Sparse & 1 \\
\hline
\end{tabular}


Each parameter was weighted and calculated based on the contribution of the parameter to flood. The flood suceptibility index are determined by the equation:

\section{Flood Suceptibility Index (FSI)}

$\mathrm{FSI}=(0,3 \times$ Landform $)+(0,3 \times$ Slope $)+(0,2 \times$ Disetance River $)+(0,2 \times$ River Density $)$

\subsection{Analysis}

This study use the qualitative analysis to reach the objectives. Qualitative analysis used by using descriptive analysis and spatial analysis. In the first objective use descriptive analysis with chart, tables, and diagrams to explaine the existing phenomenon. While on the second objective, spatial analysis is more highlighted about the spread of vulnerability in the village of Sitiarjo. ArcGis 10.1 is used to do spatial analyzes such as query database, measurement, proximity, three dimensional digital surface model, buffer, classification, digital image processing, editing function of spatial elements, tematic layer analysis, geocoding, and overlay.

\section{Results and Discussion}

\subsection{Flood Characteristics}

There are several types of flood and the flood occurred in Sitiarjo was chategorized as an overflow river flood. This kind of flood is different from flash flood because it is happen after a long process. Although the process can be missed from sighting and resulting unexpected river flood. This flood commonly occurs annually in wet season and can last up to several days or weeks until the inundation return to normal. Geologic settings were affecting Penguluran River morphology at the southern zone. There was a fault that makes Penguluran River has a streamlining orientation instead of meandering. This settings also affect the geomorphic process in Sitiarjo resulting an alluvial plain that narrowing to the south. This configuration inflict the flood to inundate way more faster to reach the settlement at the southern zone because tha plain is narrow and flanked by the structural hill. Recent flood from Penguluran River on October 2016 were reported reaching the terrace zone. The problem is that there are many settlements were built at terrace zone near the river and were impacted

\subsection{Geomorphology of Sitiarjo}

Sitiarjo Viillage located in Penguluran Watershed (Fig.2). The area has unique landscape. This area is oftenly impacted by flood. Geomorphological approach is not only investigating its earth surface processes, but also assessing and managing a great deal of environmental problems, such as geohazards [6]. We use geomorphological approach to invistigate the landforms addressing multiple aspects, such as morphology, genesis, and their morphodynamic to know the condition of flood susceptible area. The landform of the site covered into four zones, consist of as structural, karst area, fluvial, and marine zone (fig. 3). 


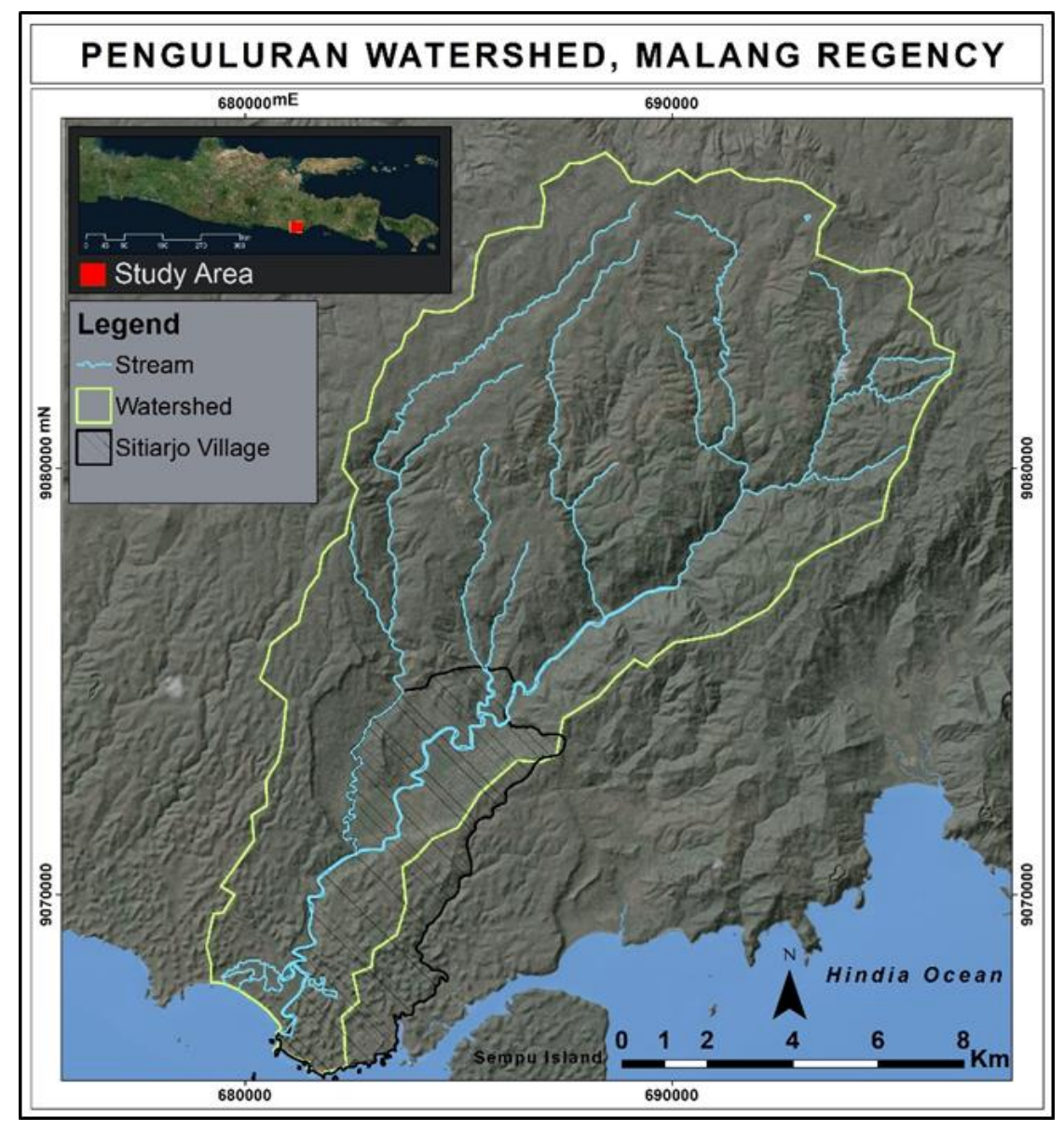

Fig. 2 Penguluran Watershed

Steep slope of structured hill is a hinterland of Penguluran Watershed (fig.2). This area has a rough morphological impression which was caused by geological structure. Slope classification was suited with elevation and surface condition on an imagery or field survey by measuring a topographic profile section. Different process is located in down slope of structural hill. The main process in this area is weathering and intensive erosion. It produces a smoother morphological impression. Another identified landscape is fault escape which is an inclined area caused by fault presence. In general, fault escape comes in a shape of arc and is dominated by mass movement from the slope above. In this location, Sitiarjo Village, the colluvial plain is an aggradation of mass movement and has a undulating morphology.

Fluvial landscape that lies in this area is a river, river valley, alluvial plain, flood plain, back swamp, and oxbow lake. There are two big rivers flow through the west of this village that are Penguluran River and Mbambangan River. Penguluran River and Mbambang River are the village boundary with Sidodadi Village. These two big rivers meet in a joint in the southern part of Sitiarjo Village, which is Rowotrate Sub-Village. Penguluran Watershed has an anastomotic flow pattern. This flow pattern was formed when river flow strikes limestone in a solutional landscape. It did not form a turn but continue to grind the karst hill. Therefore, this part of the scour becomes part of the accumulation of water. 


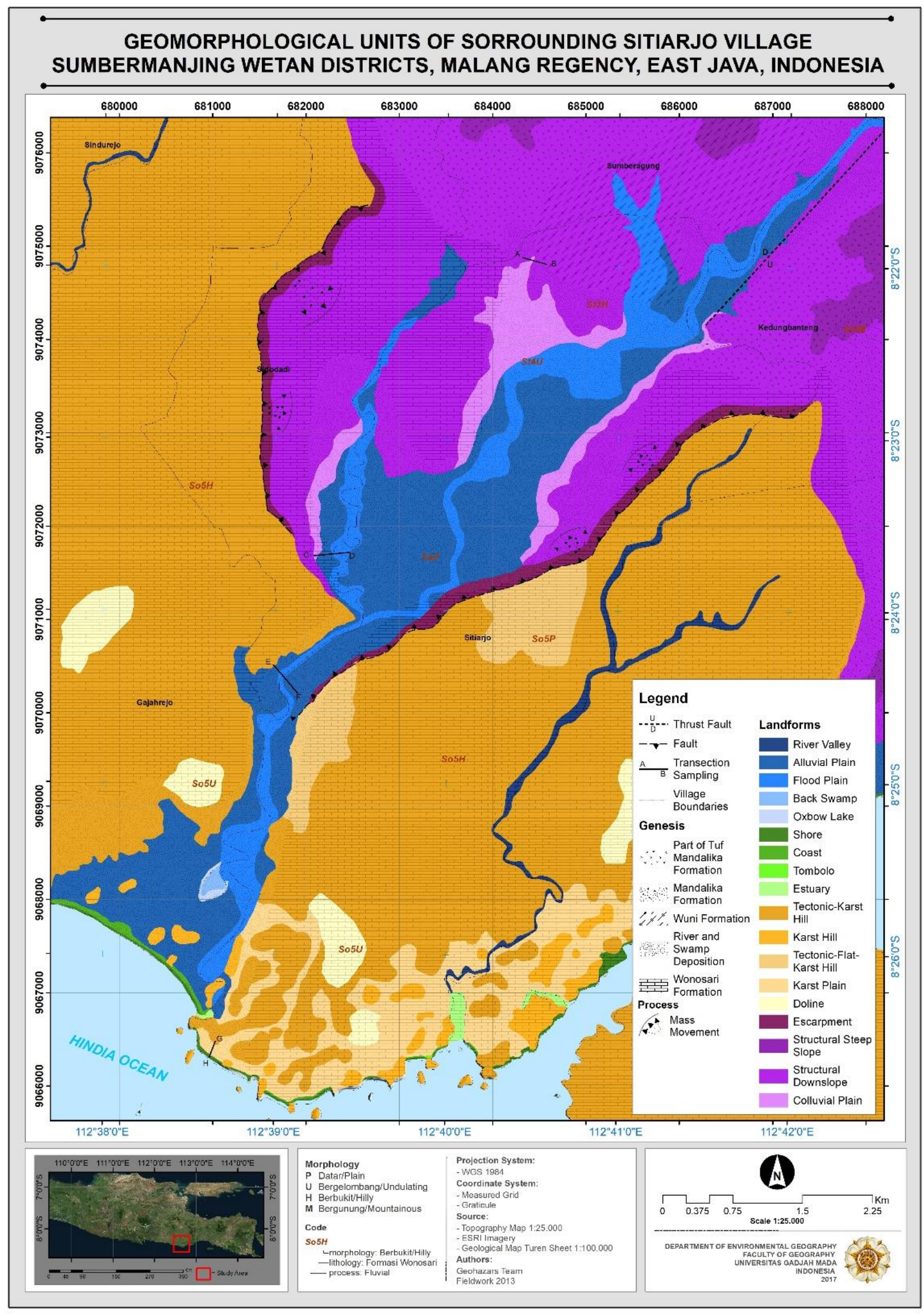

Fig. 3 Geomorphological Landform Unit of Sitiarjo 
Solutional landscape is a dissolution-controlled landscape [7]. The esult of dissolution process forms karst landscape with its characteristic are having carbonate rocks, underground river, and fractures in rocks. Marine landscape was formed by weathering, sedimentation, and transportation by wave and current [8]. Several landforms of marine are beach, old beach, tombolo, and estuary. Beach area starts from breaker zone to tidal zone while old beach area starts from tidal zone to beach cliff. Coastal area boundary starts from fluviomarine plain which is the boundary of beach cliff and current marine process.

The high surface flow causes high sediment load. According to Landsat Imagery band 764 (Fig.4-5), water zone and wet zone can be distinguished. The differences are seen in several area around rivers. Morphological change of rivers is seen clearly from the year of 1994 to 2016. In the meander, high sedimentation forms oxbow lake and shrunk ponds.

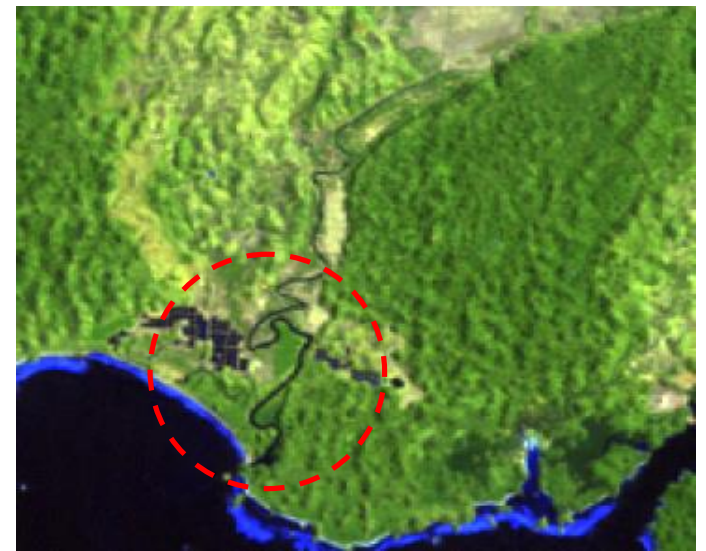

Fig. 4 Landsat Imagery 5 Band 764 (1994)

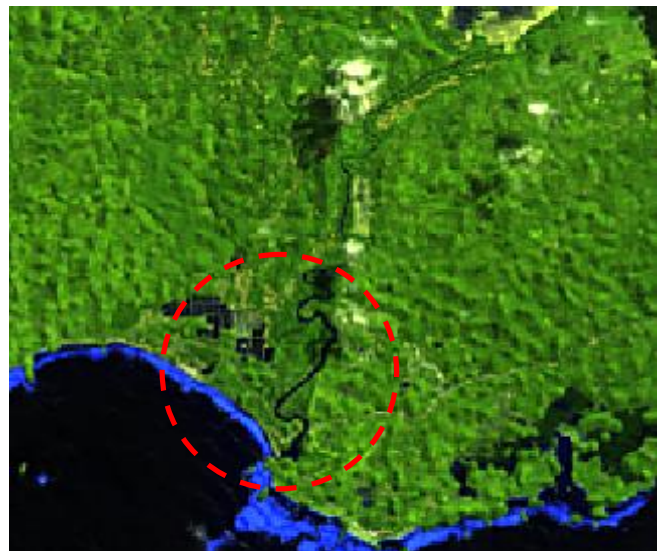

Fig. 5 Landsat Imagery 5 Band 764 (2016) 


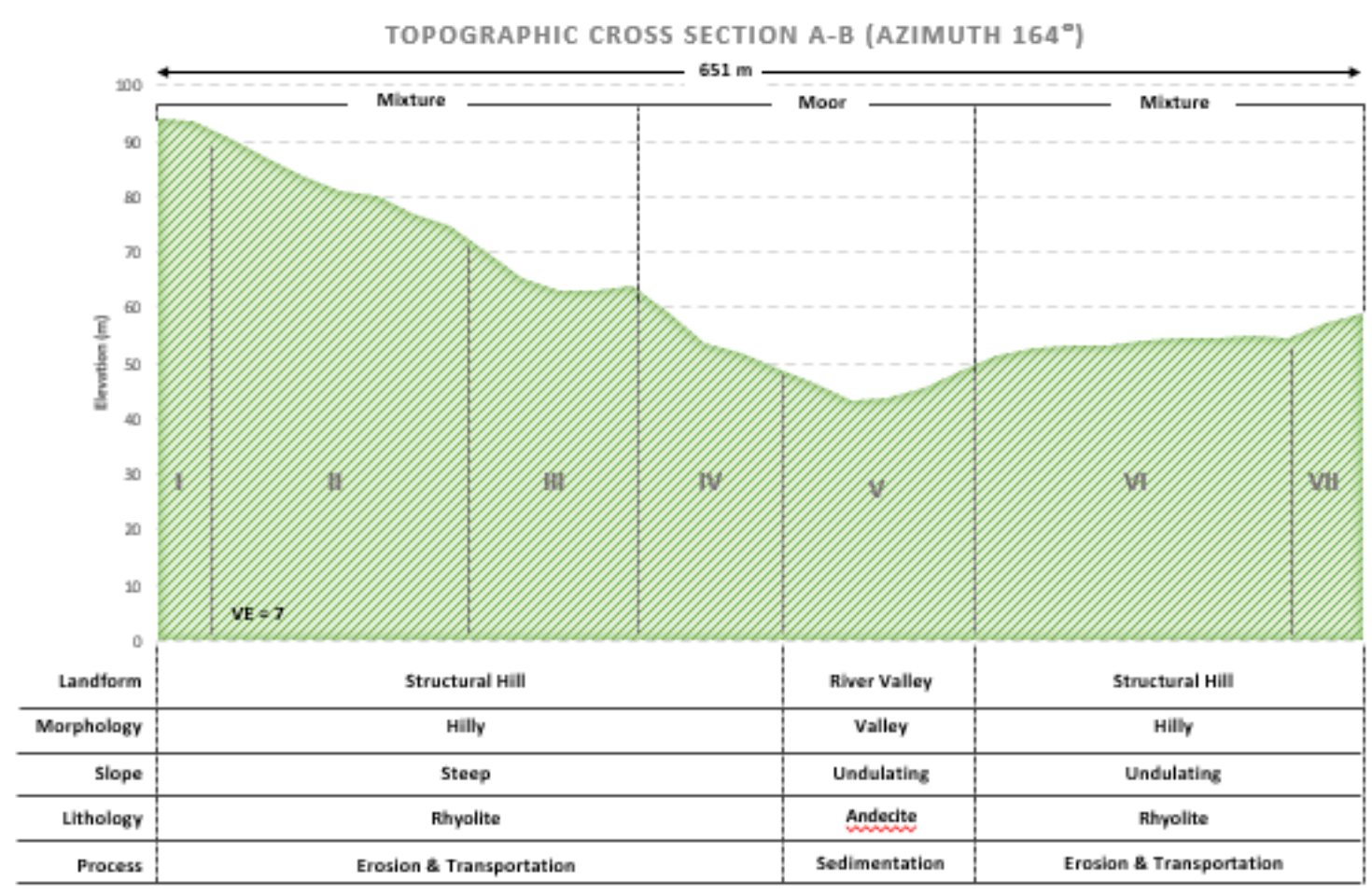

Fig. 6 Detailed topographic profile of cross section A-B

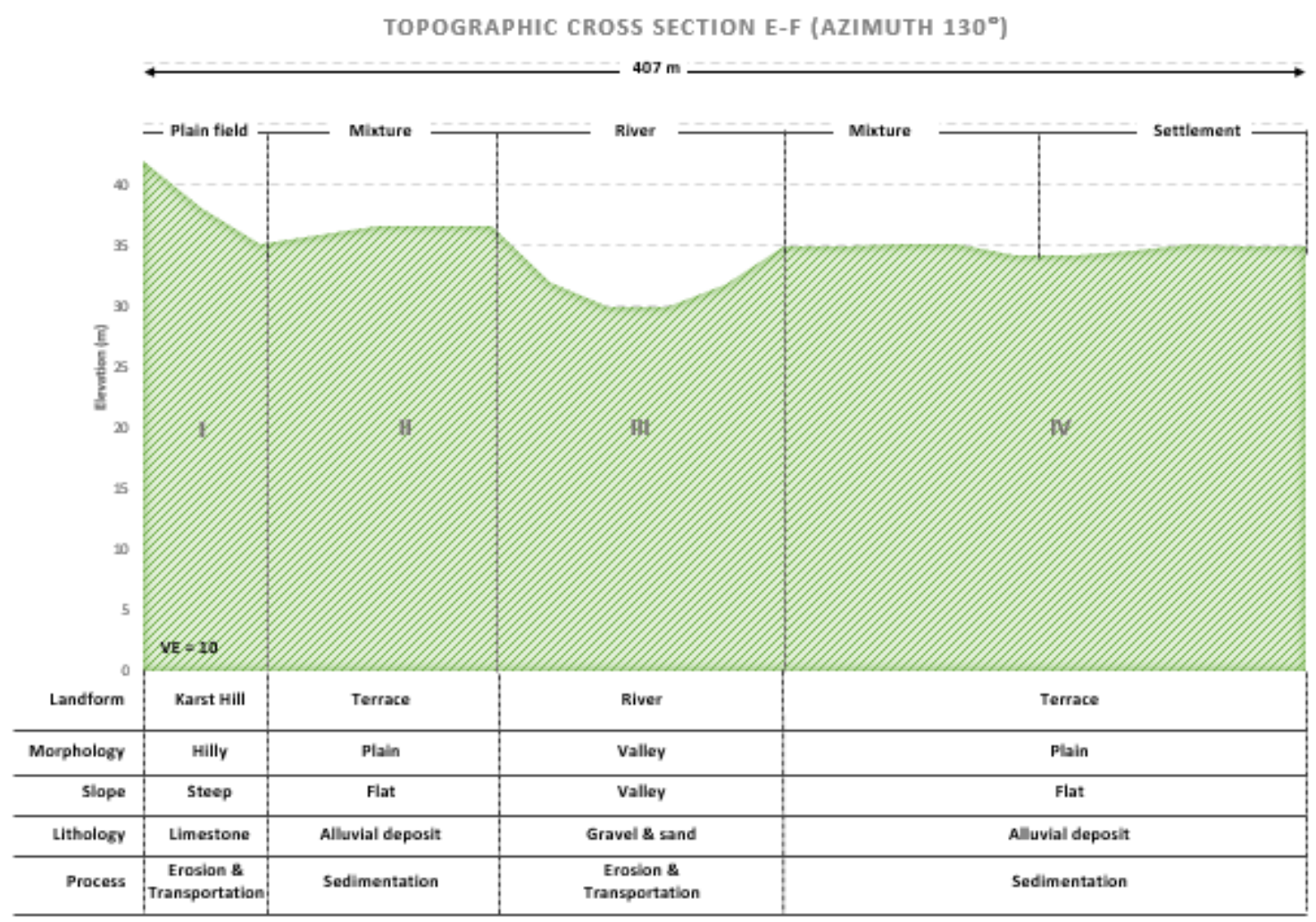

Fig. 7 Detailed topographic profile of cross section E-F 


\subsection{Flood Suceptibility}

Sitiarjo Village located in the valley between two karst hills. As located in the flood plain and downsteam of Penguluran Watershed which has round shape of watershed, this village threatened by flood river inundation. Penguluran watershed are reconstructed by the karst hills of volcanic deposition of Mandalika formation and Tuff of Mandalika Formation was aged tersier. The topographic profile depicted the distinct of steep slope in upstream and slight slope in the downstream (Fig. 8). Sitiarjo located in the downstream which an alluvial plain that naturally become water flow accumulation from the upstream. This areas is floodprone areas indicated by overflowing rivers.

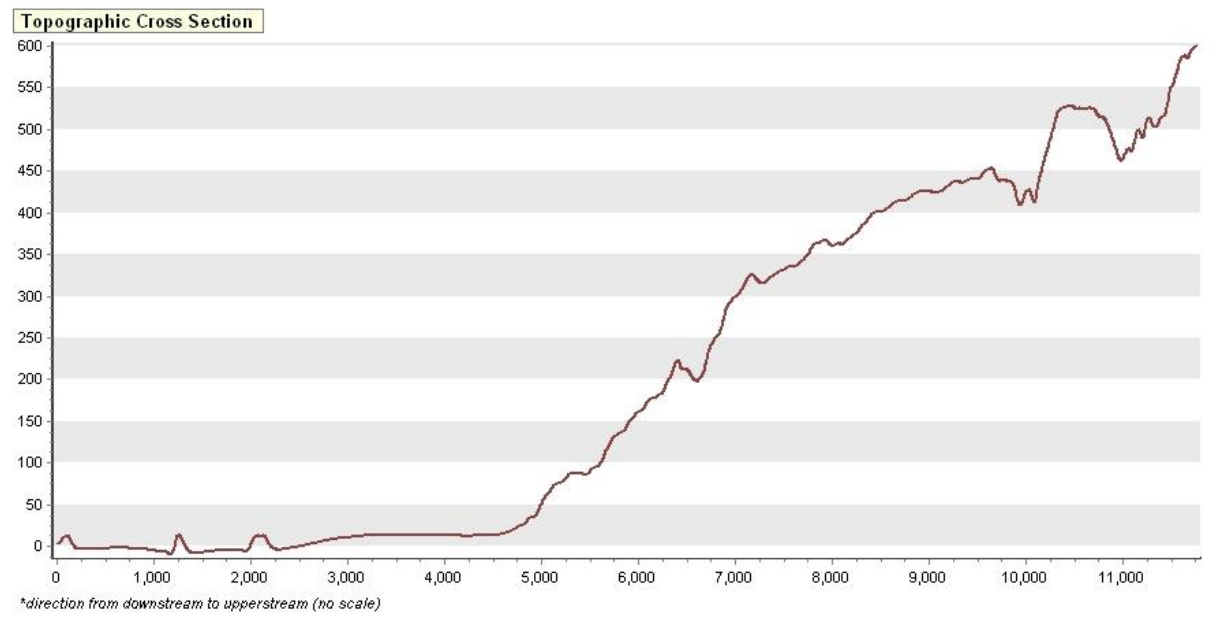

Fig. 8 Topographic Profile Section of Penguluran Watershed

Flood suceptibility map (fig.8) showed the spatial distribution of vulnerability of inundation flood. The alluvial plain was the more vulnerable of flood than karst hills. The most vulnerable was the flood plain as the river stretching through Sitiarjo Village has undergone a meandering process.

Based the field observations, many found ex-flood puddles on the walls of houses in the most flood-prone areas. While areas far from the river are not found signs of flooded puddles, but that does not mean not flooded prone. The area of flooding varies with the height and length of the inundation.

The river meandering degree decreases as it crosses the karst hillsides. At this point the creeping river meets the Mbambangan River. This is the highest vulnerable area to flood inundation. This area called Kampung Rowotrate with the recorded flood as high as the roof of the house. Geomorphology perspective found that this area is the river valley flanked by steep structural hills which means the erossion energy is ver high. The river passing through the area is a single flow outlet in the watershed. If the flow discharge exceeds the river crosssection capacity to overflow, the puddle is obstructed by a steep hill so that the inundation spread is not widespread. As a result the puddles are concentrated only in the valley and the higher until the discharge debit from the upstream begins to decrease. 
According to [9] thar the shape of a rounded watershed tends to produce a larger surface flow rate compared to an elongated watershed. This is influenced by the time of concentration, i.e. the time required to drain the water from the most distant point in the flow area to a single outlet downstream. As a result, water concentration in the end channel is faster which influences the rate and volume of surface flow.

Physiographic aspects of the watershed system as having considerable influence on surface flow [10]. Aspects of land slope affect the formation of flow runoff and hydrograph patterns. Watershed with a steep slope followed by a dense flow pattern will result in higher surface flow rates and volumes compared to sloping basins with rare ditches. Flow density affects the watershed system against incoming rainfall. A watershed with a large range of slope with a dense flow pattern is easier to drain water to the outlet than a watershed slope with a rare density of flow. Consequently a watershed with this characteristic will result in more runoff with a relatively short time. Such conditions are found in this watershed. It can be seen that the watershed has a rounded shape, has a dendritic flow pattern on the upstream and changes in parallel patterns downstream. The amount of runoff generated from the dendritic flow pattern toward the parallel flow pattern is very large and gradually rises in a short time. This causes the watershed system with these characteristics to be susceptible for flooding. 


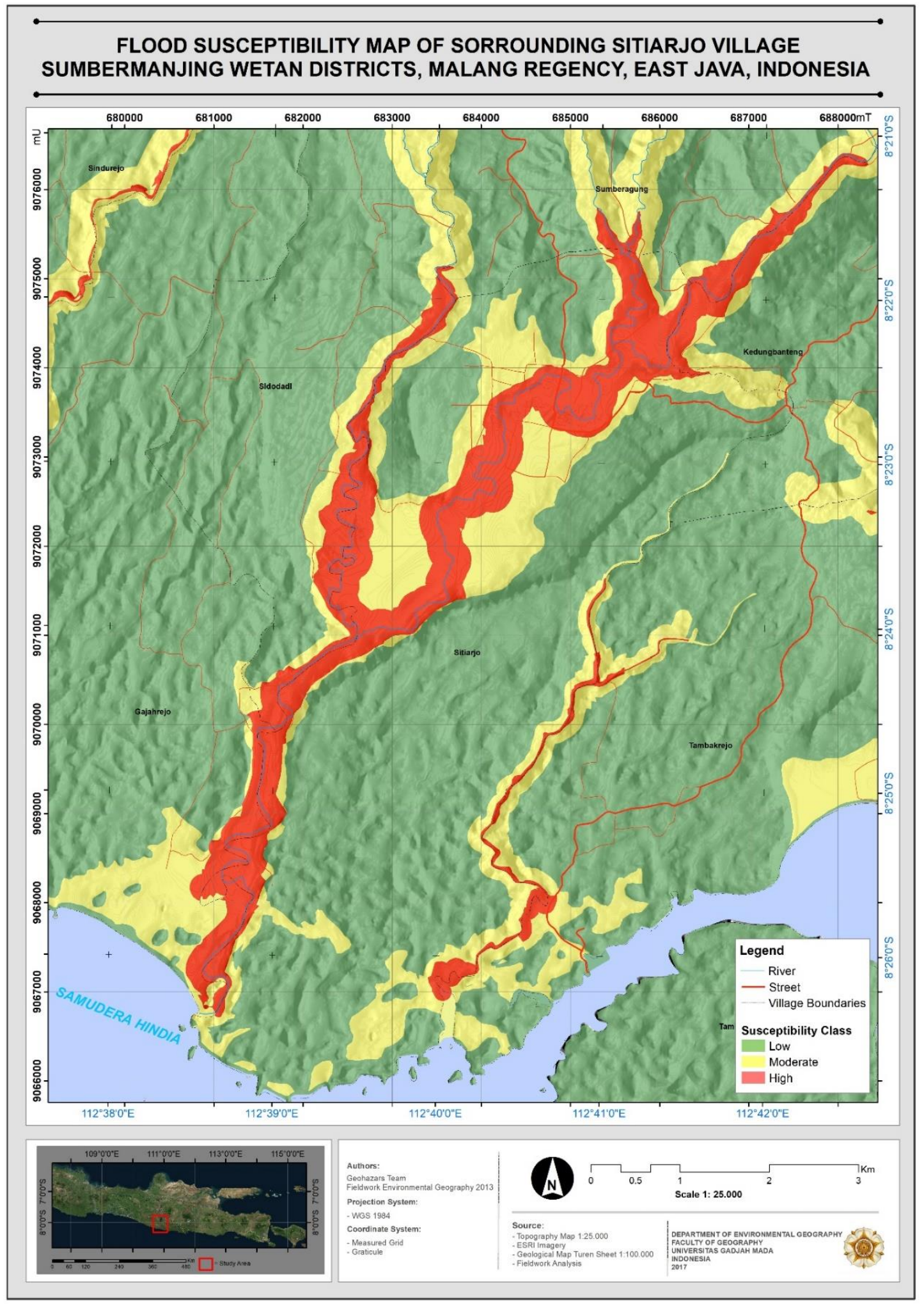

Fig. 9. Flood Suceptibility Maps of Sitiarjo Village 


\section{Conclusions}

Sitiarjo Village has unique and interesting geomorphological conditions, there are at least four landscapes consisting of structural, karst, fluvial, and marine lanscapes. The northern part of the village is the lower and middle slopes of karst hills and the southern part of the marine landscape. Landscapes structure of Sitiarjo Village is alluvial plain with Penguluran and Mbambangan river in the middle of the village and borders on the west and east flanked by karst spans.

Flood areas in Sitiarjo Village characterized as the inundation flood from the overflowing rivers. The highest vulnerable is in the middle as the alluvial plain and flood plain of the rivers and between the escarpment hills Rowotrate Village. The existing flood is a flood of inundation so that the form of land and morphoaransemen becomes the main determinant of the flood event.

\section{ACKNOWLEDGEMENT}

The dean of faculty of geography, the head of department environmental geography fo the support to this research. Mr. Djati Mardiatno, Mrs. Emilya Nurjani and Mrs. Dyah Rachmawati Hizbaron as the lecturer of the third fieldwork 2016/2017. All the fieldwork member: Galang Topan Paderi, Nuh Suranta Bukit, Briantama Asmara, Ahmad Hasrul, Fuad Dwi Rahmawan, Nur Fadhilah, Muhammad Mahendra Kumara Jati, Kabir Akbar, Vischa Findanissa P, Fauzan Aidinul Hakim, Sulthon Andalas, Zahra Octavia Setiacahyanti, and Faisal Ardian.

\section{REFERENCES}

[1] Sigat, PMI. (2013). Report of Sum of Floof Victims in Sitiarjo Village, Sumbermanjing Wetan, Malang Selatan.

[2] Filades, D.M., Pires, G.T., Cerignoni, F.J., et.al.. (2016). Morphometric analysis of the watershed of Veloso and Café streams. Journal of Cientifica Jaboticabal volume 44, n.2, ISSN: 1984-5529 pg.255-262, DOI 1984-5529.2016v44n2p255-262.

[3] Wirosoedarmono, R., Haji, A.T.S., Pramesti, E.M.. 2011. Watershed Shape Using Simodas: A Case Study of Sabu Island, NTT. Journal of Academic Research International p. 259-265. ISSN: 2223-9553 Volume 1, Issue 1, July 2011.

[4] Tehrany, M.S., Pradhan, B., and Jebur, M.N.. 2014. Flood Suceptibility Mapping Using a Novel Ensemble Weight-of-Evidence and support vector machine models in GIS. Journal of Hydrology vol. 512 p. 332-343. Elsevier.

[5] Zuidam, Van R. A.. 1983, Guide to Geomorfhology Ariel Photographic Interpretation and Mapping, ITC Enschede The Nederland

[6] Gutiérrez F. and Gutiérrez, M. (2016). Landforms of the Earth: An Illustrated Guide. ISBN: 978-3-319-26945-0. DOI 10.1007/978-3-319-26947-4. Switzerland: Springer.

[7] Srijono, Husein, S., Budiadi. 2011. Geomorphology for Teaching Book. Yogyakarta: Geology Engineering UGM. 
[8] Huggett, R. J. (2007). Fundamental of Geomorphology (2nd edition). New York: Routledge

[9] Pratomo, A. J. (2008). Flood Vulnerability Analysis in Sengkarang Watershed Area Pekalongan Regency, Central Java Province with the help of Geographic Information System. Undergraduate Thesis. Faculty of Geography Universitas Muhammadiyah Surakarta. Surakarta.

[10] Charlton, R. (2008) Fundamentals of Fluvial Geomorphology. New York: Routledge. 